\title{
PERANCANGAN SISTEM PENYIRAMAN TANAMAN OTOMATIS MEGGUNAKAN ARDUINO
}

\author{
Nofri Wandi Al-hafiz'), Erlinda ${ }^{2)}$ \\ ${ }^{1}$ Fakultas Teknik, Universitas Islam Kuantan Singingi \\ J1.Gatotsubroto KM 7Jake, Kuantan Singingi \\ email: wandie.88one@gmail.com \\ ${ }^{2}$ Fakultas Teknik, Universitas Islam Kuantan Singingi \\ Jl.Gatotsubroto KM 7Jake, Kuantan Singingi \\ email: erlinda120015@gmail.com
}

\begin{abstract}
Every plant really needs water to be able to live and as much as possible to be watered on time, because if it is too late, the growth of the plant will be hampered or even unable to develop and die, therefore there are other alternatives for plant lovers in doing plant care and not making it. We are busy in watering plants, namely using plant watering technology using Arduino electronic control, where this tool can distribute water to each plant by detecting water needs in the plant, if the planting medium on the plant is dry, it will turn on the tool and water the plant. The current method of watering plants requires energy and takes time for us to water the plants and we don't even know whether these plants need water because the surface of the soil is dry, so there is still a lot of water available inside, with this controller the water content can be determined, if the water content in the low soil, the tool will automatically turn on and water the plants.
\end{abstract}

Keywords: microcontroller, arduino, crop, automatic, soil sensor

\begin{abstract}
Abstrak
Setiap tanaman sangat memerlukan air untuk bisa hidup dan sedapat mungkin untuk tepat waktu untuk disirami, karena jika terlambat maka pertumbuhan tanaman tersebut akan terkendala atau bahkan tidak dapat berkembang dan mati, oleh karena itu ada alternatif lain untuk pecinta tanaman dalam melakukan perawatan tanaman dan tidak membuat kita sibuk dalam menyiram tanaman yakni menggunakan teknologi penyiraman tanaman menggunakan pengontrolan lektronik arduino, dimana alat ini dapat menyalurkan air ke setiap tanaman dengan mendeteksi kebutuhan air pada tanaman tersebut, jika media tanam pada tanaman tersebut kering, maka akan menghidupkan alat dan menyirami tanaman. Metode penyiraman tanaman saat ini membutuhkan tenaga dan memerlukan waktu bagi kita untuk menyirami tanaman dan bahkan kita tidak tau apakah tanaman tersebut memerlukan air karna dipermukaannya tanahnya saja yang kering sedengakan didalamnya masih banyak air tersedia, dengan alat pengendali ini dapat ditentukan kadar airnya, jika kadar air didalam tanah tersebut rendah, maka alat akan otomatis hidup dan menyirami tanaman.
\end{abstract}

Kata Kunci : mikrokontroller, arduino, tanaman, otomatis, sensor tanah 


\section{PENDAHULUAN}

Seiring dengan berkembangnya ilmu pengetahuan bidang teknologi yang dirasa sangat cepat dan sudah merambah keberbagai bidang ilmu, hal ini diperlukan untuk membuat kita lebih aktif dan ikut dalam kemajuan dan perkembangan tersebut.

Dalam hal industri perkebunan dan pertanian, penggunaan teknologi sudah sangat banyak dan salam beberapa hal dimana petani yang biasa mengerjakan, sekarang sudah dilakukan oleh mesin, salah satunya adalah dalam penyiraman tanaman dimana sesuai dengan judul yang penulis bahasan pada penelitian ini, hal sederhana tapi berpengaruh besar pada tanaman adalah penyuraman air, dimana air merupakan sumber kehidupan bagi tanaman, tentu sangat perlu diperhatikan baik waktu penyiraman air maupun banyak air yang diberikan kepada tanaman, jika tanaman kekurangan air, maka tanaman tersebut akan layu begitu pula jika tanaman tersebut banyak diberikan air, maka akarnya akan busuk dan bisa menyebabkan tanaman tersebut mati.

Sistem yang dikendalikan secara otomatis sangatlah memungkinkan untuk melakukan suatu kendali terhadap kegiatan penyiraman yang tepat waktu demi mendukung proses pertumbuhan tanaman. Untuk membuat suatu sistem yang otomatis diperlukan suatu pusat kendali dari yang akan berfungsi untuk mengendalikan seluruh kegiatan yang akan di proses oleh sistem secara umum.

Dalam penelitian kali ini, kami mencoba untuk membuat alat penyiraman otomatis menggunakan arduino dan sensor soil moisture atau alat untuk mengetahui kelembaban tanah dimana arduino sebagai pengendalinya, alat tersebut kami uji cobakan untuk penyiraman tanaman cabai dimana air yang dipompa secara otomatis berdasarkan kelembaban tanah yang dikirimkan oleh sensor.

Tidak hanya itu saja, penerapan metode budidaya tanaman yang berbeda sekalipun sangat memungkinkan untuk dilakukan didalam media tanam polibag. Artinya sistem penanaman tanaman menggunakan polibag harus memiliki kemampuan dalam menerapkan bagai bmetode penanaman yang berbeda sekalipun. Sebagai contoh dengan mengaplikasikan metode penanaman konvensional dengan metode penanaman hidroponik di dalam greenhouse yang sama misalnya.

Arduino adalah salah satu perangkat pengendali microcontroller yang bersifat opensource, dirancang untuk memudahkan penggunaan perangkat elektronik dan kendali dalam berbagai bidang. Arduino sangatlah memungkinkan untuk menjadi alat pengendali dalam sebuah sistem otomatis penyiraman tanaman.

Membangun sebuah sistem yang berbasis Arduino yang akan difungsikan untuk kegiatan penyiraman tanaman dirasa dapat menjadi sebuah alternatif lain dengan harapan dan manfaat yang akan dirasakan oleh petani.

\section{TINJAUAN PUSTAKA}

\subsection{Arduino}

Arduino merupakan komponen elektronika yang bersifat opensource, serta memiliki perangkat keras dan perangkat lunak yang mudah untuk digunakan dalam melakukan pemrograman, arduino ini bisa dikombinasikan dengan sensor sesuai dengan kebutuhan dan kegunaan.

\subsubsection{Arduino Uno}

Arduino Uno adalah papan sirkuit berbasis mikrokontroler Atmega328p. IC (intergrated circuit) ini memiliki 14 input/output digital (6 output untuk PWM), 6 analog 
input, resonator Kristal keramik 16MHz, koneksi USB,soket adaptor, pin header ICSP, dan tombol reset.Hal inilah yang dibutuhkan untuk mensupport mikrokontroler secara mudah terhubung dengan kabel power USB atau kabel power supply adaptor AC ke DC atau juga battery. Uno berbeda dari semua board mikrokontrol diawal-awal yang tidak menggunakan chip khusus driver FTDI USB-to-serial. Sebagai penggantinya penerapan USB-to-serial adalah ATmega16U2 versi R2 (versi sebelumnya ATmega8U2). Versi Arduino Uno Rev.2 dilengkapi resistor ke 8U2 ke garis ground yang lebih mudah diberikan ke mode DFU.[1]

Sebelum arduino uno ada seperti saat ini, kita harus merakit komponen - koponen elektronika dimana komponen yang digunakan terdiri dari transistor, resistor, dan IC untuk menjalankan instruksi yang diinginkan, tetapi komponen - komponen tersebut cendrung susah dicari dan harus membeli melalui pemesanan terlebih dahulu. Penggunaan arduino saat ini cukup membantu untuk melakukan riset pembuatan rangkaian elektronika[6].

\subsubsection{Mikrokontroler}

Mikrokontroller merupakan sebuah sistem komputer dimana seluruh atau sebagian besar elemennya dikemas dalam satu chip IC (Integrated Circuit), sehingga sering disebut single chip microcomputer. Mikrokontroller ini juga merupakan sebuah sistem komputer yang memiliki satu atau beberapa tugas yang spesifik, beberapa dengan PC yang memilik beragam fungsi. Perbedaan yang lain adalah perbandingan RAM dan ROM yang sangat besar antara mikrokontroller dengan komputer. Dalam mikrokontroller ROM jauh lebih besar dibanding RAM, sedangkan dalam komputer atau PC RAM jauh lebih besar dibandingkan ROM. Mikrokontroler memiliki kemampuan untuk mengolah serta memproses data sekaligus juga dapat digunakan sebagai unit kendali, maka dengan sekeping chip yaitu mikrokontroller kita dapat mengendalikan suatu alat.[2]

Mikrokontroller, sebagai trobosan teknologi mikrokontroller dan mikrokomputer, hadir memenuhi kebutuhan pasar (market need) dan teknologi baru. Sebagai teknologi baru, yaitu teknologi semi konduktor dengan kandungan transistor yang lebih bayak namun hanya membutuhkan ruang kecil serta dapat diproduksi secara missal (dalam jumlah banyak) sehingga harga menjadi lebih murah (dibandingkan mikroprosesor). Sebagai kebutuhan pasar, mikrokontroller hadir untuk memenuhi selera industry dan para konsumen akan kebutuhan dan keinginan alat-alat bantu. Tidak seperti sistem komputer, yamg mampu menangani berbagai macam program aplikasi (misalnya pengolah kata, pengolah angka, dan lain sebagainya), mikrokontroller hanya bisa digunakan untuk satu aplikasi tertentu saja. Perbedaan lainnya terletak pada perbandingan RAM dan ROM-nya. Pada sistem komputer perbandingan RAM dan ROM-nya besar, artinya program-program pengguna disimpan dalam ruang RAM yang relative besar, sedangkan rutin-rutin antarmuka perangkat keras disimpan dalam ruang ROM yang kecil. Sedangkan pada mikrokontroller, perbandingan ROM dan RAM-nya yang besar artinya program kontrol disimpan dalam ROM (bisa Masked ROM atau Flash PEROM) yang ukurannya relative lebih besar, sedangkan RAM digunakan sebagai tempat penyimpanan sementara, termasuk register-register yang digunakan pada mikrokontroller.[3]

Secara umum mikrokontroller terbagi menjadi 3 keluarga yang ada dipasaran.Setiap keluarga mempunyai ciri khas dan karakteristik sendiri-sendiri berikut pembagian keluarga dalam mikrokontroller.

1. Keluarga MCS51 
Mikrokontroller ini termasuk dalam keluarga mikrokontroller CISC.Sebagian besar intruksinya dieksekusi dalam 12 siklus clock. Mikrokontroller ini berdasarkan arsitektur Harvard dan meskipun awalnya dirancang untuk aplikasi mikrokontroller chip tunggal, sebuah mode perluasan telah mengizinkan sebuah ROM luar 64KB dan RAM luar 64KB diberikan alamat dengan cara jalur pemilihan chip yang terpisah untuk akses program dan memori data. Salah satu kemampuan mikrokontroller 8051 adalah pemasukan sebuah mesin pemroses Boolean yang mengijinkan operasi logika Boolean tingkat bit dapat dilakukan secara langsung dan secara efisien dalam register internal dan RAM. Karena itulah MCS51 digunakan dalam rancangan awal PLC (Programmable Logic Control)[4].

\section{AVR}

Mikrokontroller Vegard's Risc atau sering disingkat AVR merupakan mikrokontroller RISC 8 bit. Karena RISC iniah sebagian besar kode intruksinya dikemas dalm satu siklus clock AVR adalah jenis mikrokontroller yang paling sering dipakai dalam bidang elektronika dan instrumentasi. Secara umum, AVR dapat dikelompokan dalam 4 kelas.Pada dasarnya yang membedakan masing-masing kelas adalah memori, peripheral dan fungsinya.Keempat kelas tersebut adalah keluarga ATTiny, keluarga AT90Sxx, keluarga ATMega dan AT86RFxx[5].

3. PIC

PIC adalah keluarga mikrokontroller tipe RISC buatan Mikrochip Teknologi Bersumber dari PIC1650 yang dibuat oleh Divisi Mikroelektronika General Instrument Teknologi Microchip tidak menggunakan PIC sebagai akronim melainkan nama brandnya ialah PICmicro. Hal ini karena PIC singkatan dari Peripheral Interface Controller, tetapi General Instrument mempunyai akronim PIC1650 sebagai Programmabel Intelegent Computer.PIC pada awalnya dibuat menggunakan teknologi. General Instrument 16 bit CPU yaitu CP1600. Bit PC dibuat pertama kali 1975 untuk meningkatkan performa system peningkatan pada I/O. Saat ini PIC telah dilengkapi dengan EPROM dan komunikasi serial, UAT, kernel control motor serta memori program dari 512 word hingga 32 word. Iword disini sama dengan I intruksi bahasa assembly yang bervariasi dari 12 hingga 16 bit, tergantung dari tipe PICmicro tersebut. Pada awalnya, PIC merupakan kependekan dari Programmable Interface Controller.Tetapi pada perkembangannya berubah menjadi Programmable Interface Computer.PIC termasuk keluarga mikrokontroller berarsitektur Harvard yang dibuat oleh Microchip Technology. Awalnya dikembangkan oleh Divisi Mikroelektronik General Instrument dengan nama PIC1640. Sekarang Mikrochip telah mengumumkan pembuatan PIC-nya yang keenam.PIC cukup popular digunakan oleh para developer dan para penghobi ngoprek karena biayanya yang rendah, ketersedian dan penggunaan yang luas, database aplikasi yang besar, serta pemograman (dan pemograman ulang) melalui hubungan port serial yang terdapat pada computer[6].

Adapun mikrokontroller yang dipakai peneliti adalah mikrokontroller jenis Arduino uno sebagai pengontrol elektronik untuk membaca dan menulis data untuk tersambung ke komputer. Arduino uno adalah suatu mikrokontroller pada ATMEGA 2650 yang mempunyai 54 input output digital yang mana 16 pin digunakan sebagai PWM keluaran, 16 masukan analog, dan didalamnya terdapat $16 \mathrm{MHZ}$ osilator Kristal, USB koneksi, power, ICSP, dan tombol reset. KINERJA Arduino ini memerlukan dukungan mikrokontroller dengan menghubungkan pada suatu komputer dengan USB kabel untuk menghidupkan menggunakan arus AC atu DC dan bias juga dengan menggunakan baterai[9]. 


\subsection{UML}

(UML) adalah sebuah bahasa yang telah menjadi standar dalam industri untuk visualisasi, merancang dan mendokumentasikan sistem piranti lunak sebuah sistem. UML lebih mengedepankan penggunaan diagram untuk menggambarkan aspek dari sistem, karena tergolong bahasa visual yang lebih mudah dan lebih cepat dipahami dibandingkan dengan bahasa pemrograman[8].

Alat bantu yang digunakan dalam perancangan berorientasi objek berbasiskan UML adalah sebagai berikut:

\section{Use Case Diagram}

Use case diagram merupakan pemodelan untuk kelakuakn (behavior) sistem informasi yang akan dibuat. Use case digunakan untuk mengetahui fungsi apa saja yang ada di dalam sistem informasi dan siapa saja yang berhak menggunakan fungsi-fungsi tersebut[12]. Simbol-simbol yang digunakan dalam Use Case Diagram yaitu:

\section{Tabel 1 Simbol Use Case Diagram}

\begin{tabular}{|c|c|}
\hline Gambar & Keterangan \\
\hline & $\begin{array}{l}\text { Use Case menggambarkan fungsionalitas } \\
\text { yang disediakan sistem sebagai unit yang } \\
\text { bertukar pesan antar unit dengan aktor, } \\
\text { yang dinyatakan menggunakan kata kerja. }\end{array}$ \\
\hline & $\begin{array}{l}\text { Aktor adalah Abstraction dari orang atau } \\
\text { sistem yang lain yang mengaktifkan fungsi } \\
\text { dari target sistem. Perlu dicatat bahwa aktor } \\
\text { berinteraksi dengan Use Case, tetapi tidak } \\
\text { memiliki kontrol terhadap use case. }\end{array}$ \\
\hline & $\begin{array}{l}\text { Asosiasi antara aktor dan use case, } \\
\text { mengindikasikan siapa atau apa yang } \\
\text { meminta interaksi secara langsung dan } \\
\text { bukannya mengindikasikan data. }\end{array}$ \\
\hline & $\begin{array}{l}\text { Asosiasi antara aktor dan use case untuk } \\
\text { mengindikasikan bila aktor berinteraksi } \\
\text { secara pasif dengan sistem }\end{array}$ \\
\hline $\begin{array}{l}---------> \\
\quad<\text { include }>\end{array}$ & $\begin{array}{l}\text { Include, merupakan di dalam use case lain } \\
\text { (required) atau pemanggilan use case oleh } \\
\text { use case lain. }\end{array}$ \\
\hline $\begin{array}{c}<--------- \\
\ll<\text { extends }>\end{array}$ & $\begin{array}{l}\text { Extend, merupakan perluasan dari use case } \\
\text { lain jika kondisi atau syarat terpenuhi. }\end{array}$ \\
\hline
\end{tabular}

Sumber [7] 


\section{Context Diagram}

Context Diagram adalah diagram yang terdiri dari suatu proses dan menggambarkan ruang lingkup suatu sistem. diagram konteks merupakan level tertinggi dari dfd yang menggambarkan seluruh input ke sistem atau output dari sistem. ia akan memberi gambaran tentang keseluruan sistem. sistem dibatasi oleh boundary (dapat digambarkan dengan garis putus). dalam diagram konteks hanya ada satu proses. tidak boleh ada store dalam context diagram[10]. Gambar yang di gunakan dapat dilihat di tabel 2 sebagai berikut :

Tabel 2 Simbol Context Diagram

\begin{tabular}{|c|c|c|}
\hline \multicolumn{2}{|l|}{ Gambar } & \multirow[t]{2}{*}{ Keterangan } \\
\hline $\begin{array}{l}\text { Notasi } \\
\text { Yourdan/Demiarco }\end{array}$ & Notasi Gane \& Sarson & \\
\hline & & $\begin{array}{l}\text { simbol external entity } \\
\text { terminal menggambarkan asal } \\
\text { atau tujuan data di luar sistem }\end{array}$ \\
\hline & & $\begin{array}{l}\text { System lingkaran } \\
\text { menggambarkan entitas atau } \\
\text { proses dimana aliran data } \\
\text { masuk ditansformasikan ke } \\
\text { aliran data keluar }\end{array}$ \\
\hline & & $\begin{array}{l}\text { simbol aliran data } \\
\text { meggambarkan aliran data }\end{array}$ \\
\hline & & $\begin{array}{l}\text { simbol file menggambarakan } \\
\text { tempat data disimpan }\end{array}$ \\
\hline
\end{tabular}

\section{Sumber :[7]}

\section{Data Flow Diagram}

Data Flow Diagram adalah komponen yang digunakan dalam pembuatan suatu kontext diagram dan DFD dari rancangan sistem yang dibahas dalam penulisan tugas akhir. Simbol dari flow diagram dapat dilihat pada tabel 3.

\section{Tabel 3 Data Flow Diagram}

\begin{tabular}{|l|l|l|}
\hline Simbol & Nama simbol & \multicolumn{1}{|c|}{ Keterangan } \\
\hline & $\begin{array}{l}\text { Eksternal } \\
\text { entity } \\
\text { (kesatuan luar) }\end{array}$ & $\begin{array}{l}\text { Simbol ini merupakan sumber atau tujuan } \\
\text { data suatu bagian /orang yang berada di luar } \\
\text { sistem tapi berhubungan dengan sistem } \\
\text { tersebut, baik itu memasukkan data maupun } \\
\text { mengambil data dari sistem. }\end{array}$ \\
\hline \hline & $\begin{array}{l}\text { Pimbol ini digunakan untuk melakukan proses } \\
\text { pengolahan data yang menunjukkan suatu } \\
\text { kegiatan yang mengubah aliran data masuk } \\
\text { (input) menjadi aliran data keluar (output). }\end{array}$ \\
\hline & $\begin{array}{l}\text { Penyimpanan } \\
\text { data (data } \\
\text { source) }\end{array}$ & $\begin{array}{l}\text { Simbol ini berfungsi sebagai tempat } \\
\text { penyimpanan dokumen/file yang dibutuhkan } \\
\text { dalam suatu sistem informasi. }\end{array}$ \\
\hline
\end{tabular}




\begin{tabular}{|l|l|l|}
\hline$\longleftrightarrow \mid \uparrow$ & Aliran data & $\begin{array}{l}\text { Simbol ini menunjukkan arus dalam proses, } \\
\text { dimana simbol aliran data ini mempunyai } \\
\text { nama sendiri. }\end{array}$ \\
\hline
\end{tabular}

\section{Sumber :[7]}

\section{Flowchart}

Flowchart atau dalam bahasa Indonesia sering disebut dengan Diagram Alir ini dipergunakan dalam industri manufakturing untuk menggambarkan proses proses operasionalnya sehingga mudah dipahami dan mudah dilihat berdasarkan urutan langkah dari suatu proses ke proses lainnya.Berikut gambar symbol symbol flowchart :

a. Flow Direction Symbols

Yaitu, simbol yang dipakai untuk menghubungkan antara simbol yang satu dengan simbol lainnya atau disebut juga connecting line. Flow Direction Symbols dapat dilihat pada Tabel 4 :

\section{Tabel 4 Flowchart}

\begin{tabular}{|l|l|l|}
\hline & Arus / Flow & $\begin{array}{l}\text { Penghubung antara } \\
\text { prosedur / proses }\end{array}$ \\
\hline Connector & $\begin{array}{l}\text { Simbol keluar / masuk } \\
\text { prosedur atau proses } \\
\text { dalam lembar / halaman } \\
\text { yang sama }\end{array}$ \\
\hline Off-line Connector & $\begin{array}{l}\text { Simbol keluar / masuk } \\
\text { prosedur atau proses } \\
\text { dalam lembar / halaman } \\
\text { yang lain }\end{array}$ \\
\hline
\end{tabular}

Sumber :[7]

b. Processing Symbols

Merupakan simbol yang menunjukkan jenis operasi pengolahan dalam suatu prosedur. Processing Symbols dapat dilihat pada tabel 5 :

Tabel 5 Flowchart

\begin{tabular}{|l|l|l|}
\hline & Process & $\begin{array}{l}\text { Simbol yang menunjukkan } \\
\text { pengolahan yang dilakukan } \\
\text { Komputer }\end{array}$ \\
\hline Predefined Process & $\begin{array}{l}\text { Simbol untuk kondisi yang akan } \\
\text { menghasilkan beberapa } \\
\text { kemungkinan jawaban / aksi }\end{array}$ \\
\hline & $\begin{array}{l}\text { Simbol untuk mempersiapkan } \\
\text { penyimpanan yang akan } \\
\text { digunakan sebagai tempat } \\
\text { pengolahan didalam storage }\end{array}$ \\
\hline
\end{tabular}




\begin{tabular}{|l|l|l|}
\hline & Manual Input & $\begin{array}{l}\text { Simbol untuk pemasukan data } \\
\text { secara manual on-line keyboard }\end{array}$ \\
\hline
\end{tabular}

\section{Sumber : [7]}

c. Input Output Symbols

Simbol yang dipakai untuk menyatakan jenis peralatan yang digunakan sebagai media input atau output. Input Output Symbols dapat dilihat pada tabel 6 :

\section{Tabel 6 Flowchart}

\begin{tabular}{|c|c|l|}
\hline & Input-Output & $\begin{array}{l}\text { Simbol yang menyatakan } \\
\text { proses input dan output tanpa } \\
\text { tergantung dengan jenis } \\
\text { peralatannya }\end{array}$ \\
\hline Document & $\begin{array}{l}\text { Simbol yang menyatakan input } \\
\text { berasal dari dokumen dalam } \\
\text { bentuk kertas atau output di } \\
\text { cetak dikertas }\end{array}$ \\
\hline$C$ & Disk and On-line Storage & $\begin{array}{l}\text { Simbol untuk menyatakan } \\
\text { input berasal dari disk atau } \\
\text { output dimpan ke disk. }\end{array}$ \\
\hline
\end{tabular}

Sumber :[7]

\subsection{Prototype}

Langkah awal untuk model prototyping dapat berhasil sesuai dengan yang diinginkan adalah melalui tahapan tahapan sebagai berikut:

1. Pengumpulan kebutuhan Dimana tahap awal antara pelanggan dan pengembang bersama-sama mendefinisikan format seluruh perangkat lunak, mengidentifikasikan semua kebutuhan dan garis sistem yang akan dibuat.

2. Membangun Prototyping Membangun prototyping dengan membuat perancangan sementara yang berfokus pada penyajian kepada pengguna.

3. Evaluasi Protyping Evaluasi ini dilakukan oleh pengguna apakah prototyping yang sudah dibangun sudah sesuai dengan keinginan pengguna. Jika sudah maka langkah 4 akan diambil, jika tidak prototyping direvisi dengan mengulangi langkah 1,2, dan 3.

4. Mengkodekan System Dalam tahap ini prototyping yang sudah disepakati kedalam bahasa pemprograman yang sesuai.

5. Menguji system. Setelah sistem sudah menjadi suatu perangkat lunak yang siap pakai, harusdites dahulu sebelum digunakan. Pengujian ini dilakukan dengan White Box, Black Box, Basis Path, pengujian arsitektur dan lain-lain.

6. Evaluasi System Pengguna mengevaluasi apakah sistem yang sudah jadi sudah sesuai dengan yang diharapkan. Jika sudah sesuai, langkah 7 dilakukan; jika tidak, ulangi langkah 4 dan 5.

7. Menggunakan System Perangkat lunak yang telah diuji dan diterima pengguna siap untuk digunakan [5]. 


\section{METODE PENELITIAN}

Lokasi penelitian adalah di Fakultas Peranian Universitas Islam Kuantan Singingi dimana Fakultas Pertanian Universitas Islam Kuantan Singingi mempunyai 3 program studi, yakni program Studi Peternakan, Program Studi Agroteknologi, Program Studi Agribisnis dengan luas lahan pertanaian yang pada diolah adalah seluas lebih kurang 1 Ha untuk tujuan penelitian mahasiswa. Dalam penelitian ini metode yang dilakukan adalah:

1. Penelitian Lapangan

penelitian yang dilakukan dengan melakukan pengamatan dilapangan sehingga dapat dilakukan simulasi terhadap sistem yang dibuat, penelitian ini dapat dilakukan dengan cara :

a. Wawancara

Yaitu metode pengumpulan data dan cara mengadakan tanya jawab secara langsung, kepada pihak yang mempunyai wewenang di dalam sekolah untuk mendapatkan gambaran yang menyeluruh tentang sistem informasi yang ada. Wawancara memerlukan syarat penting yakni terjadinya hubungan yang baik dan demokratis antara responden dengan penanya. Fungsi wawancara dalam penelitian adalah :

1. Mendapat informasi langsung dari responden (metode primer)

2. Mendapat informasi, ketika metode lain tidak dapat di pakai (metode skunder)

b. Observasi

Yaitu metode pengumpulan data dengan cara mempelajari semua dokumen dan catatan yang memuat data-data yang diperlukan.

2. Penelitian Perpustakaan

Yaitu metode pengumpulan data yang dilaksanakan dengan membaca dan mempelajari buku-buku sebagai bahan referensi yang berhubungan dengan masalah penyusunan tugas akhir ini.

3. Penelitian Laboratarium

Yaitu kegiatan penulis dalam mengolah informasi yang diperoleh,lalu merancang aplikasi yang diinginkan berdasarkan data dan informasi yang ada. Alat yang dibutuhkan dalam pembuatan sistem ini adalah sebagai berikut:

A. Perangkat Keras

1. Processor Intel inside

2. Memory $2 G B$

3. Hardisk $350 \mathrm{~GB}$

4. Solder

5. Multitester

6. Sedot timah

7. Timah solder

B. Perangkat Lunak

1. Sistem Operasi Windows 7

2. Arduino compiler 
Alur metode penelitian dapat dilihat pada gambar 1 dibawah ini :

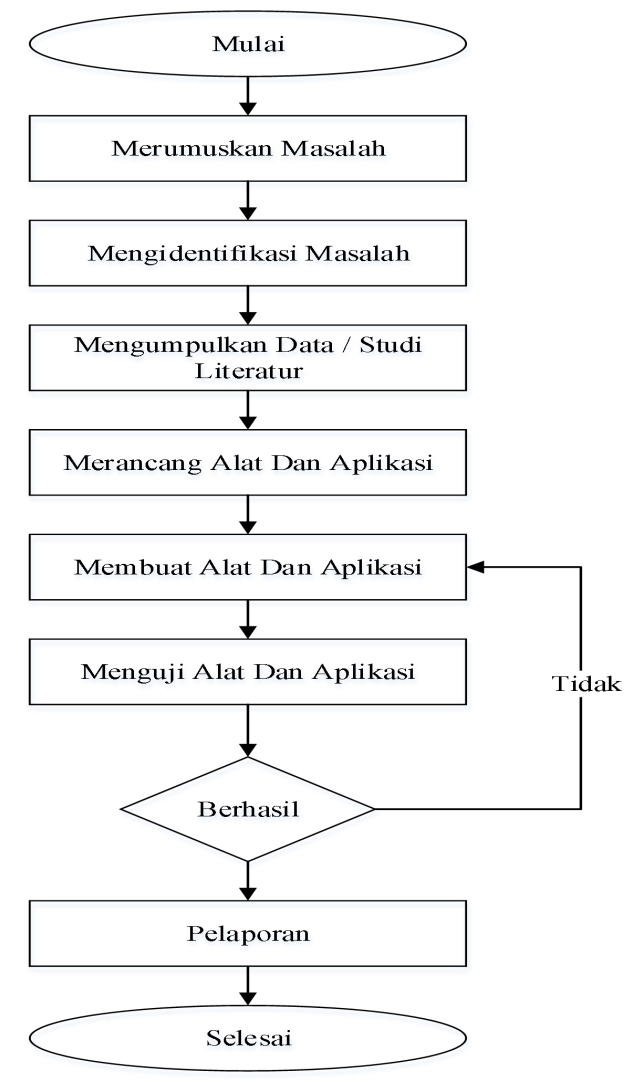

Gambar 1. Alur metode penelitian

\section{HASIL DAN PEMBAHASAN}

\subsection{Perancangan Sistem}

Berdasarkan analisa sistem yang sedang berjalan dapat diusulkan sistem yang baru, yaitu sistem monitoring kelembaban tanah dan suhu menggunakan sensor tanah, sistem ini secara umum berupa rangkaian elektronik. Perancangan sistem monitoring kelembaban tanah dan suhu ini memerlukan dua jenis sensor yakni Soil Moisture Sensor dan DHT11 Sensor yang akan di tancapkan ke dalam tanah guna mendeteksi kelembaban tanah dan suhu pada greenhouse tersebut. Setelah pembacaan sensor selesai selanjutnya sensor akan mengirimkan data ke arduino untuk diproses.

Rangkaian elektronik ini berfungsi untuk memberikan data informasi yang dikirim dari pembacaan sensor kelembaban tanah yang ditanamkan di tempat penyemaian bibit dan sensor DHT11 untuk mendeteksi. Setiap perubahan kelembaban tanah mencapai kelembaban minimal maka arduino akan otomatis mengaktikan relay dan menghidupkan penyiram tanaman, menyiram tanaman sampai kelembaban maksimal. Jika kelembaban telah mencapai maksimal maka relay akan mati. Perancangan secara umum dari sistem yang di usulkan dapat di lihat pada gambar 2 berikut : 


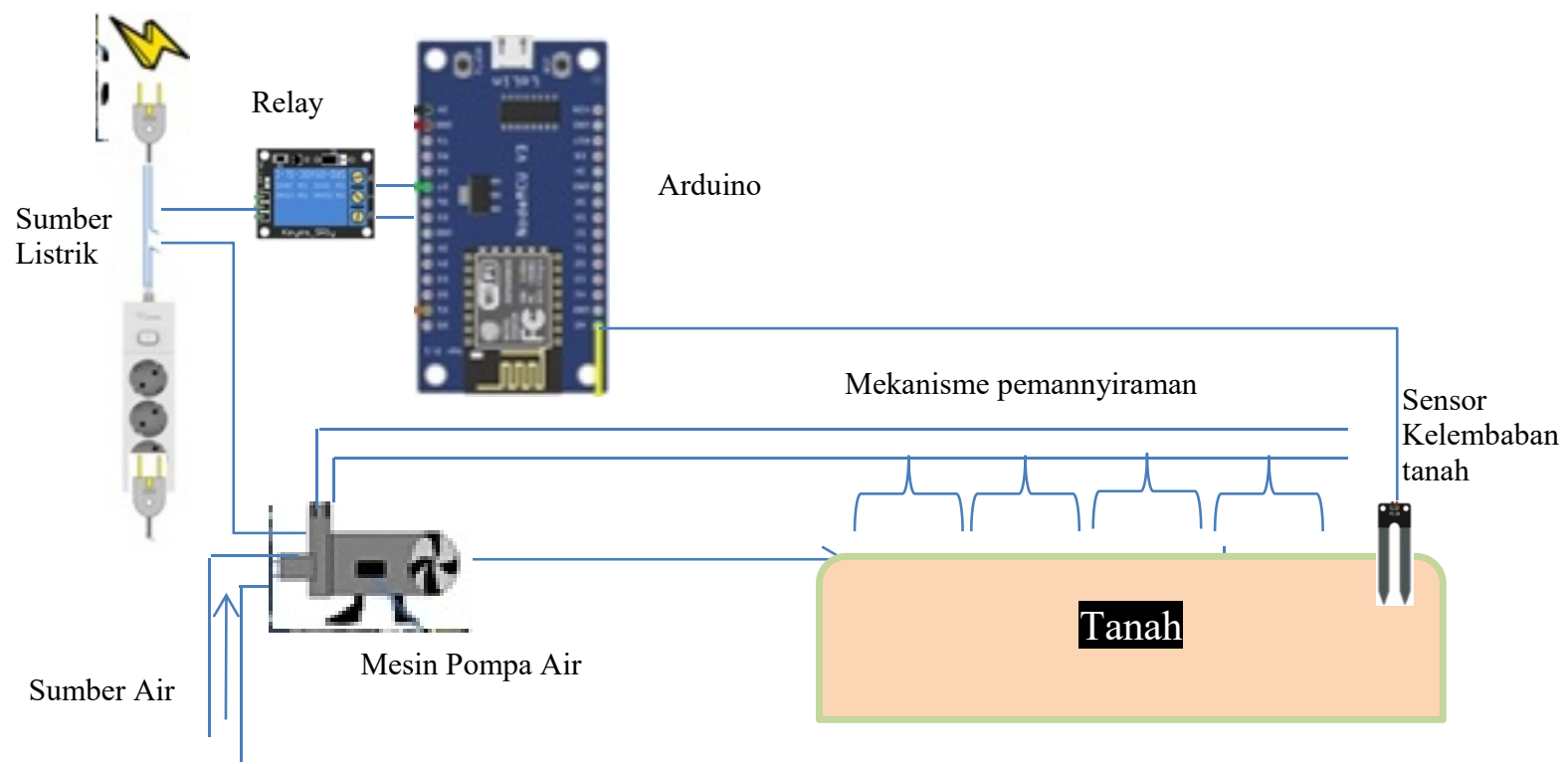

Gambar 2. Rancangan Sistem Yang Di Usulkan

\subsubsection{Perancangan Diagram}

Perancangan diagram sistem digambarkan secara umum pada context Diagram, Use Case Diagram, Data Flow Diagram, Block Diagram.

\subsubsection{Context Diagram}

Sub-sub bab ini merupakan penjabaran setiap external entity/etitas luar secara keseluruhan yang digambarkan melalui context diagram. Context diagram merupakan pendefinisian terhadap sistem yang akan dirancang yang bersifat menyeluruh. Context diagram bertujuan untuk memudahkan dalam proses penganalisaan sistem yang dirancang secara menyeluruh. Context diagram berfungsi sebagai media, yang terdiri dari suatu proses dan beberapa buah external entity. Context diagram yang dimaksud dapat dilihat pada gambar 3 .

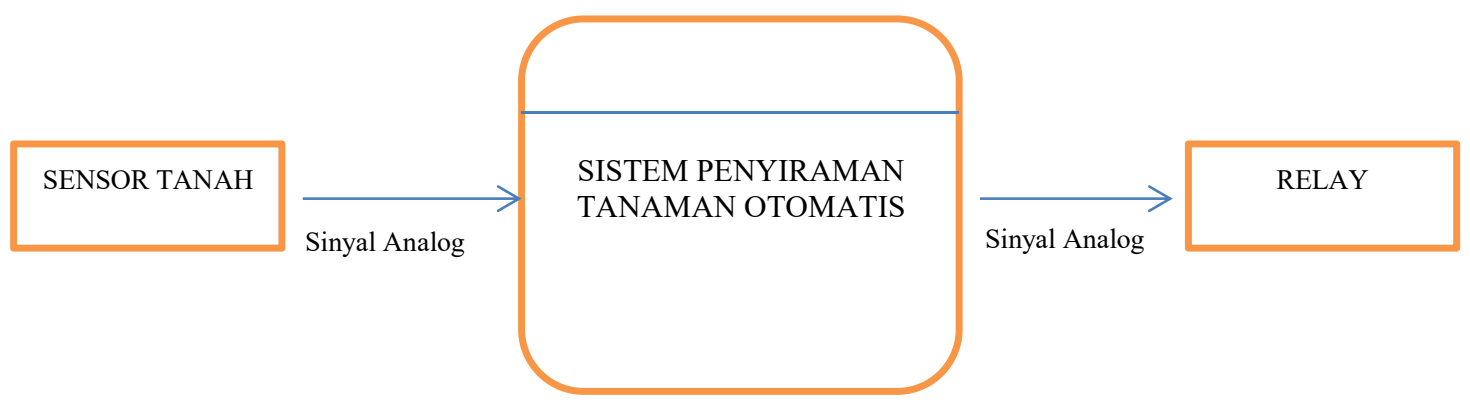




\section{Gambar 3. Context Diagram}

Pada gambar 3. Context diagram di atas menjelaskan bahwa alur kerja dari sistem yang penulis rancang adalah proses pengolahan data dari pembacaan sensor berupa sinyal analog dan diteruskan ke microkontroler lalu diproses dan di eksekusi sesuai dengan program bahasa $\mathrm{C}$ dan dikirimkan ke modul output berupa Relay, setelah itu perintah untuk menghidup dan mematikan mesin pompa air diinstruksikan dari mikrokontroler.

\subsubsection{Block Diagram}

Perancangan blok diagram dilakukan dengan tujuan untuk mempermudah realisasi sistem yang akan dibuat. Block diagram sistem monitoring kelembaban tanah dan suhu greenhouse tanaman bawang merah berbasis IOT ini ditunjukkan pada gambar 4.5 berikut :

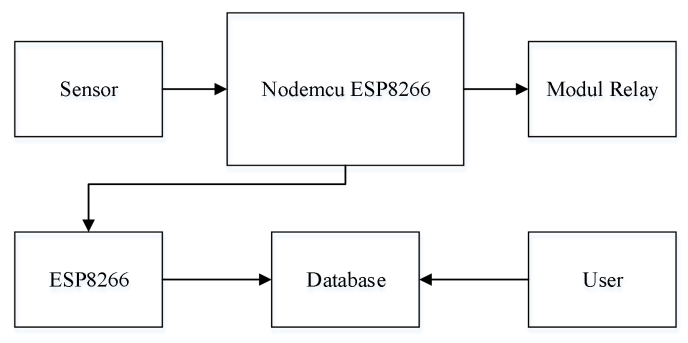

Gambar 4. Block Diagram

Pada gambar 4. block diagram di atas dapat dilihat bahwa sistem informasi kelembaban tanah dan suhu tanah ini diawali dengan sensor-sensor sebagai input yang mengirimkan data sinyal analog setelah itu akan diproses oleh Nodemcu ESP8266 yang telah di program sesuai dengan kebutuhan memonitoring kelembaban tanah dan suhu tersebut. Setelah data di proses oleh arduino maka selanjutnya menyalakan relay untuk menghidupkan mesin air guna melakukan penyiraman tanaman sebagaimana program yang di buat, jika kelembaban tanah kurang dari minimal maka relay kan aktif dan jika kelembaban tanah telah mencapai maksimal maka relay akan mati.

\subsubsection{Perancangan Perangkat Keras}

Perangkat keras di sini merupakan perangkat keras arduino uno yang di gunakan sebagai pendukung sistem monitoring kelembaban tanah dapat dilihat sebagai berikut :

\subsubsection{Soil Moisture Sensor}

Pada Penelitian ini digunakan Soil Moisture fc-28 sensor yang berfungsi sebagai pendeteksi kelembaban tanah. Adapun rangkaian Soil Moisture sensor fc-28 yang dihubungkan ke mikrokontroler NodeMCU ESP8266 menggunakan Breadboard ditampilkan pada gambar 5 berikut :

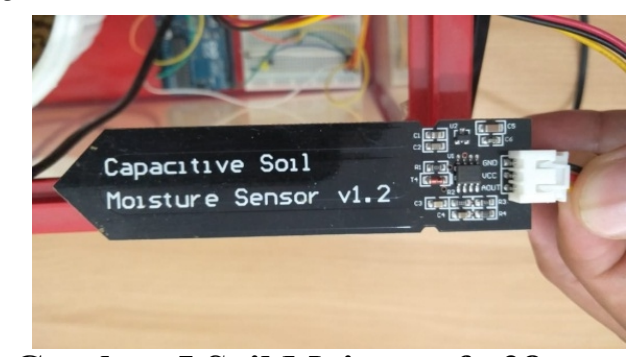

Gambar 5 Soil Moisture fc-28 sensor 


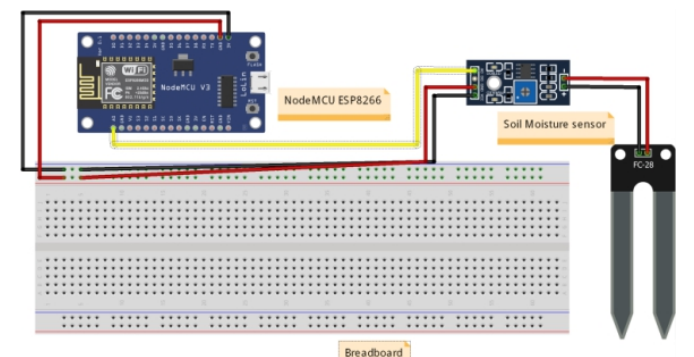

\section{Gambar 6. Rangkaian Soil Moisture fc-28 sensor}

Pada gambar 6 Rangkaian Soil Moisture fc-28 sensor di atas dapat dilihat bahwa antara NodeMCU dengan Soil Moisture fc-28 sensor dihubungkan menggunakan beberapa kabel jumper dimana pasangan pin.

\subsubsection{Modul Relay}

Pada Penelitian ini digunakan Modul Relay 1 cahanel karena relay ini hanya digunakan untuk menghidupkan penyiram tanaman secara otomatis, jika sensor kelembaban tanah mengirimkan sinyal analog ke NodeMCU ESP8266 dengan kelembaban minimal maka relay akan aktif dan sebaliknya jika sinyal analog kelembaban mencapai maksimal maka relay akan mati. Adapun rangkaian Modul relay 1 chanel yang dihubungkan ke mikrokontroler NodeMCU ESP8266 menggunakan Breadboard ditampilkan pada gambar 6 berikut :

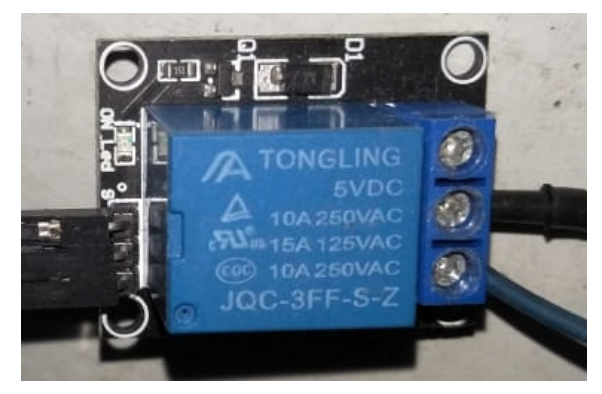

Gambar 7 Modul Relay

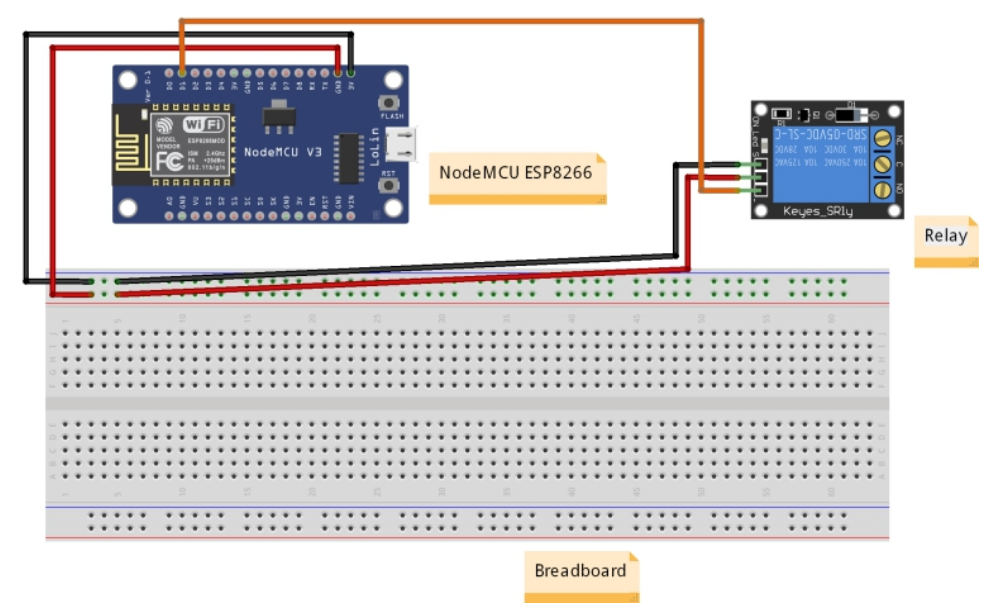

Gambar 8 Rangkaian Modul Relay 1 Chanel 
Pada gambar 8 Rangkaian Modul Relay 1 Chanel di atas dapat dilihat bahwa antara NodeMCU dengan Modul Relay 1 Chanel dihubungkan menggunakan beberapa kabel jumper dimana pasangan pin dapat dilihat pada table berikut :

\subsubsection{Perancangan Perangkat Keseluruhan}

Adapun perancangan sistem secara keseluruhan dalam sistem ini seperti gambar dibawah ini.

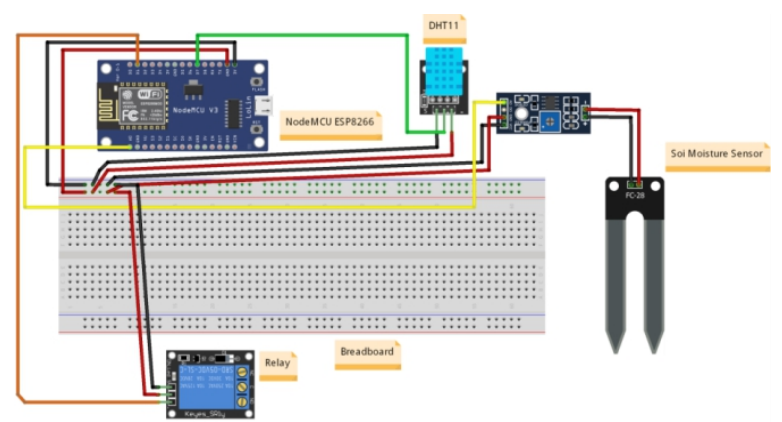

Gambar 9. Desain Perangkat Keras Sistem

\subsubsection{Perancangan Perangkat lunak Arduin ide}

Dalam pembangunan sistem monitoring ini memerlukan dua perangkat lunak yakni, perangkat lunak Arduino IDE dan perangkat lunak smartphone sebagai media pemantauannya. Kedua perangkat lunak tersebut dapat dilihat sebagai berikut :

\subsubsection{Perangkat Lunak NodeMCU}

Dalam perancangan perangkat lunak, Nodemcu ESP8266 menggunakan perangkat lunak Arduino IDE. Bahasa yang digunakan dalam perancangan lunak adalah bahasa $\mathrm{C} / \mathrm{C}++$ dengan beberapa tambahan untuk perancangan Sistem monitoring kelemaban tanah dan suhu tanah. perancangan perangkat lunak di atas dapat dilihat bahwa sistem bekerja dimulai dari menghidupkan atau mengaktifkan sistem, yaitu dengan memberikan daya tegangan $5 \mathrm{~V}$ 1A melalui adapter yang terhubung ke Board NodeMCU, setelah hidup Sensor-sensor yang terpasang akan aktif dan melakukan pendeteksian kelembaban tanah dan suhu pada ruangan greenhouse. Bersamaan dengan itu ESP8266 juga aktif dan mencari sinyal wifi untuk terhubung ke internet guna mengirimkan data ke database. Setelah sensor aktif dan mendeteksi kelembaban dan suhu, setelah itu data sensor akan dikirim ke database menggunakan koneksi dari ESP8266 tadi bersamaan dengan itu data kelembaban tanah akan diproses untuk pengaktifan relay, jika kelembaban tanah kurang dari 50\% maka relay akan aktif dan sebaliknya jika kelembaban mencapai $70 \%$ makan relay akan mati.

\subsection{Implementasi Sistem}

Setelah dianalisis sistem yang berjalan, dirancang sistem yang diusulkan. Implementasi ini bertujuan untuk mengaplikasikan perancangan sistem yang baru, agar masalah yang ada pada Fakultas Teknik Universitas Islam Kuantan Singingi dapat di atasi dengan baik serta memberi solusi pemecahan masalah dari kondisi yang ada.

\subsubsection{Rangkaian Penyiraman Tanaman Otomatis}

Sesuai dengan rancangan sistem diatas maka rancangan alat penyirman seperti gambar dibawah : 


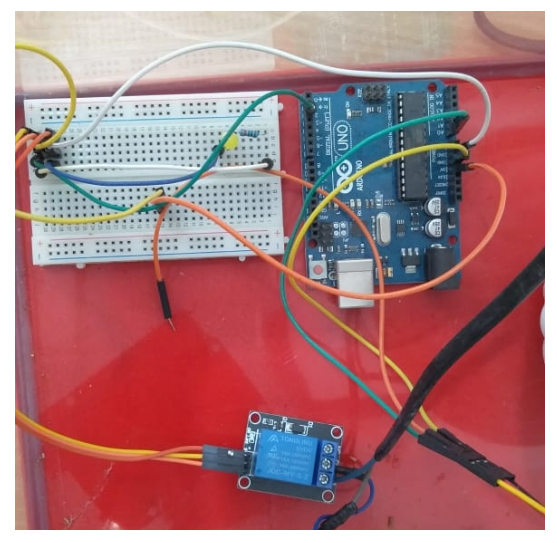

\section{Gambar 10. Rangkaian Elektronik Penyiraman Tanaman Otomatis}

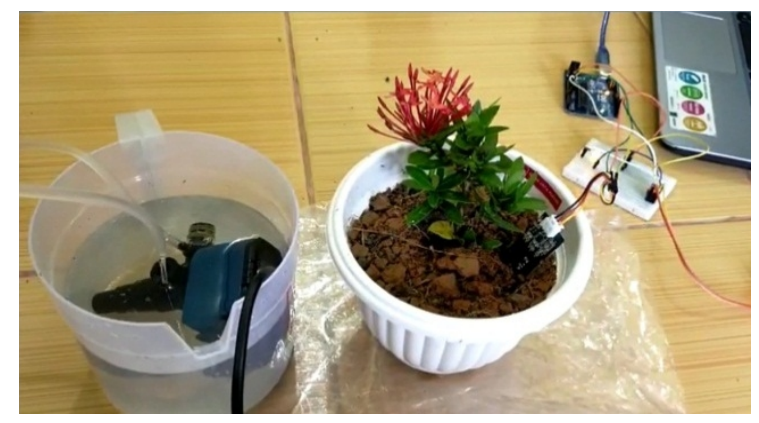

Gambar 11. Rangkaian Penyiraman Tanaman Otomatis

\section{SIMPULAN}

Setelah Sistem Monitoring Kelembaban Tanah ini dirancang, dibangun, kemudian diuji, maka dapat diambil bebrapa kesimpulan sebagai berikut :

1. Pembangunan sistem monitoring kelembaban tanah dan suhu greenhouse tanaman bawang merah yakni pada proses pembibitannya mengandalkan sistem detekdi kelembaban tanah.

2. Pemantauan kelembaban tanah dan suhu pembibitan tanaman bawang dapat dilakukan dimana saja dan kapan saja, pengecekan kelembaban tanah tidak lagi dilakukan dengan datang langsung ke greenhouse atau rumah pembibitan sehingga tidak mengganggu kegiatan lain dan pertanian tetap berjalan dengan semestinya.

Ujicoba yang dilakukan pada media tanam sederhana, menunjukkan setiap komponen berfungsi dengan baik serta dapat digunakan pada lahan yang luas, sensor tanah yang berfungsi sebagai pendeteksi dan sebagai input sinyal untuk mikrokontroler berfungsi dengan baik sesuai dengan perintah yang dimasukkan kedalam sistem.

\section{UCAPAN TERIMAKASIH}

Alhamdulillahhirabbil'Alamin, serta puji dan syukur kepada Allah SWT sehingga sampai saat ini masih diberikan nikmat serta rahmatNya yang tek terhingga dan dicukupkan semua kebutuhan dimudahkan semua urusan dalam menjalani penelitian ini, serta tak lupa pula kepada pihak - pihak yang telah membantu dalam proses pelaksanaan penelitian ini, 
kepada Ketua Prodi Teknik Informatika, Dekan Fakultas Pertanian, Ketua Lembaga Penelitian serta jajaran yang telah membantu pelaksanaan penelitian ini.

\section{DAFTAR PUSTAKA}

[1] Husdi. (2010). Monitoring Kelembaban Tanah Pertanian Menggunakan Soil Moisture Sensor Fc-28 Dan Arduino Uno. Gorontalo: universitas ichsan.

[2] Febrianti, tina. Mardiana Dewi. Asnidar. (2018). "Komparasi Pendapatan Usahatani Tanaman Hortikultura di UPT Bulupountu Jaya Kabupaten Sigi Sulawesi Tengah”. Seminar Nasional Dalam Rangka Dies Natalis UNS Ke 42

[3] Andalia, Fanny. Eko Budi Setiawan. (2015). "Pengembangan Sistem Informasi Pengolahan Data Pencari Kerja Pada Dinas Sosial Dan Tenaga Kerja Kota Padang”. Jurnal Ilmiah Komputer dan Informatika (KOMPUTA) : ISSN : 20899033

[4] Sari, Salisa Kurnia. Dwi Remawati. Bebas Widada. "Sistem Informasi Monitoring Dan Evaluasi Belajar Siswa Berbasis Web Dan Sms Gateway Di Sdit Nurul Istiqlal Klaten”. ISSN: 1693-1173

[5] Hakim, Wahyu Lukman. (2011). "Pengertian Prototype". http://www.scribd.com/doc/58298607/Pengertian-Prototype

[6] Sari, Marti Widya. Hafid Hardyanto. (2016). “Implementasi Aplikasi Monitoring Pengendalian Pintu Gerbang Rumah Menggunakan App Inventor Berbasis Android". Jurnal EKSIS Vol 09 No 01 Mei 2016: 20 - 28

[7] Ade Hendini. (2016). "Pemodelan UML Sistem Informasi Monitoring Penjualan Dan Stok Barang (Studi Kasus : Distro Zhezha Pontianak)". Jurnal Khatulistiwa Informatika.

[8] Sing, N. International Journal of Innovative Research in Computer and Communication Engineering (An ISO 3297: 2007 Certified Organization) Vol. 4, Issue 9, September 2016.

[9] Hermansyah. (2016). "Sistem Informasi Pengolahan Data Siswa Berbasis Web Pada Smk Labor Pekanbaru”. Pekanbaru: Universitas Sultan Syarif Kasim Riau.

[10] Permana, Eka," Rancang Bangun Sistem Monitoring Suhu Ruangan Bagian Pembukuan Berbasis Web Meggunakan Mikrokontroler Arduino Uno R3" Jurnal Teknologi Informasi Dan Komunikasi, Issn: 2252-4517, 5, 2018.

[11] Nainggolan, H. dan Yusfi, M., "Rancang Bangun Sistem Kontrol Suhu dan Kelembaban Relatif Pada Ruangan dengan Menggunakan Motor DC Berbasis Mikrokontroler ATMEGA8535”, Jurnal Fisika Unand (JFU), Jur. Fisika Unand, Padang (2013).

[12] Sing, N. International Journal of Innovative Research in Computer and Communication Engineering (An ISO 3297: 2007 Certified Organization) Vol. 4, Issue 9, September 2016. 